\title{
State of Environment in Kathmandu Valley, Nepal: A Special Review
}

\author{
Ashutosh Mohanty \\ International Center for Integrated Mountaineering Development, Nepal \\ Corresponding e-mail: amohanty@icimod.org
}

\begin{abstract}
The purpose of the "State of Environment: Kathmandu Valley, Kathmandu Nepal: A Special Review", is to examine the current status of the environment of the Kathmandu Valley and the suburban areas of Kathmandu, Lalitpur, and Bhaktapur districts. The Articles analyses the emerging environmental problems and promotes specific recommendations for future action. The analysis also examines various problem and pressures due to population pressure and environmental changes happening with an alarming speed. This analysis presents an alarming picture of a rapidly deteriorating environment. The paper summarizes the policy gaps, analyses and identifies a number of measures for amelioration of existing problems and prevention of future environmental deterioration in the Kathmandu Valley.
\end{abstract}

\section{Introduction}

Kathmandu is one of the fastest growing cities of the South Asia. It is also one of the populous valleys in the Himalayan belt which also called as a temple valley in the region. With the growth of pollution and socio economic development, infrastructure expansion brings lot of pressure towards environment of the Kathmandu Valley.

Kathmandu Valley lies at 1,300 masl and is located between latitudes $27^{\circ} 32^{\prime} 13^{\prime \prime}$ and $27^{\circ} 49^{\prime} 10^{\prime \prime}$ north and longitudes $85^{\circ} 11^{\prime} 31^{\prime \prime}$ and $85^{\circ} 31^{\prime} 38^{\prime \prime}$ east. Its three districts, Kathmandu, Lalitpur, and Bhaktapur, cover an area of 899 square kilometers, whereas the area of the valley as a whole is 665 square kilometers. The valley encloses the entire area of Bhaktapur district, $85 \%$ of Kathmandu district and $50 \%$ of Lalitpur district.

The valley is bowl shaped and surrounded by the Mahabharat mountain range on all sides. There are four hills acting as forts of the valley, Phulchowki in the South East, Chandragiri/ Champa Devi in the South West, Shivapuri in the North West, and Nagarkot in the North East. The highest altitudes are 2,166m (in Bhaktapur), 2,732m (in Kathmandu), and 2,831 m (in Lalitpur).

Table 2.1: Distribution of Population by District, 1991-2001

\begin{tabular}{|l|c|c|c|c|c|}
\hline \multicolumn{1}{|c|}{ District } & 1991 & $\begin{array}{c}\text { \% of total } \\
\text { population }\end{array}$ & 2001 & $\begin{array}{c}\text { \% of total } \\
\text { population }\end{array}$ & $\begin{array}{c}\text { Annual growth } \\
\text { rate }\end{array}$ \\
\hline Lalitpur & 257,086 & 1.39 & 337,785 & 1.46 & 2.73 \\
\hline Bhaktapur & 17,295 & 0.94 & 225,461 & 0.97 & 2.65 \\
\hline Kathmandu & 675,341 & 3.65 & $1,081,845$ & 4.67 & 4.71 \\
\hline KVD* & $1,105,379$ & 5.98 & $1,645,091$ & 7.10 & 4.06 \\
\hline
\end{tabular}

Source: $C B S 2003 b$

*Kthmandu Valley districts. 


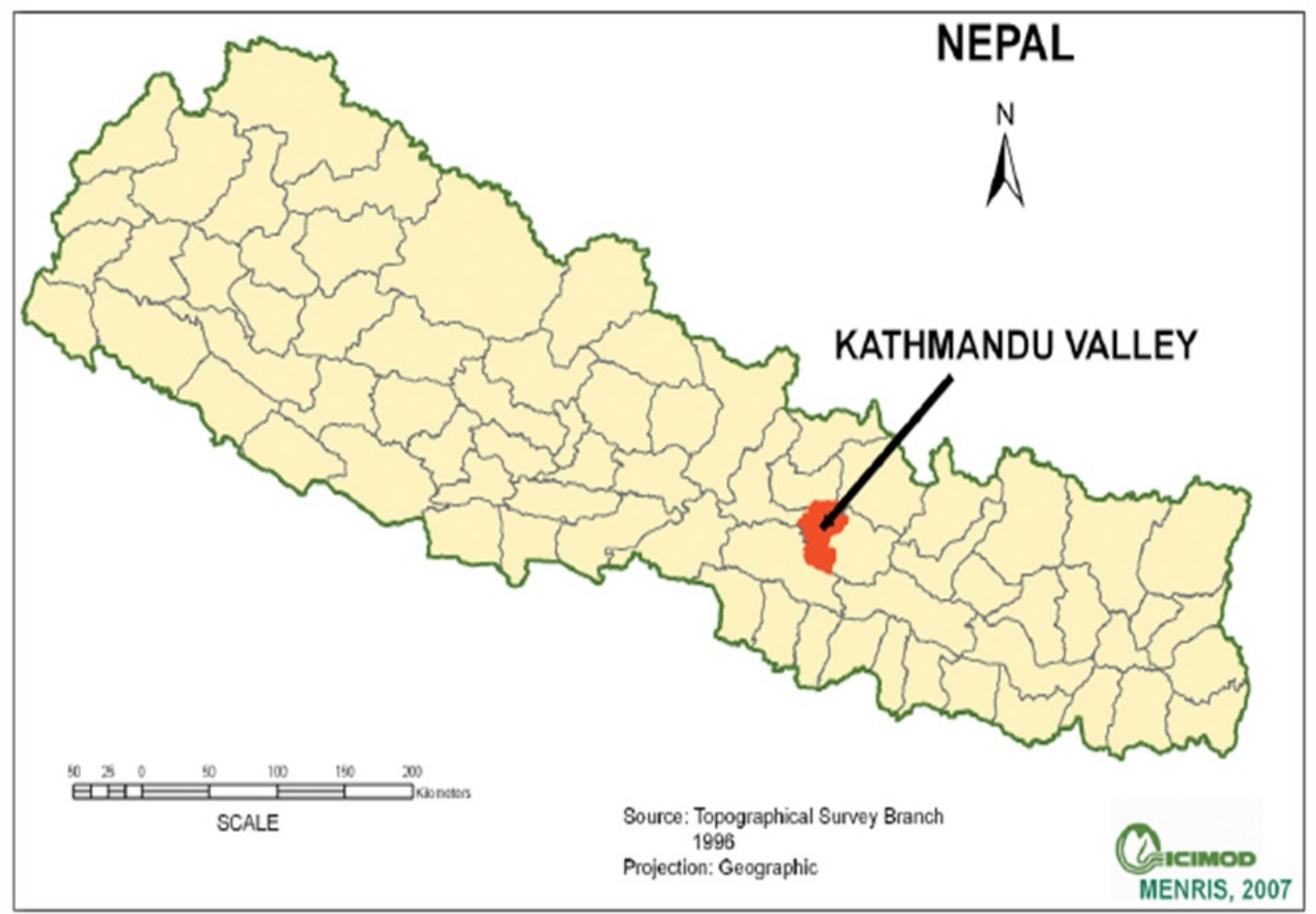

I. SOURCE: ICIMOD PublicATION 2007

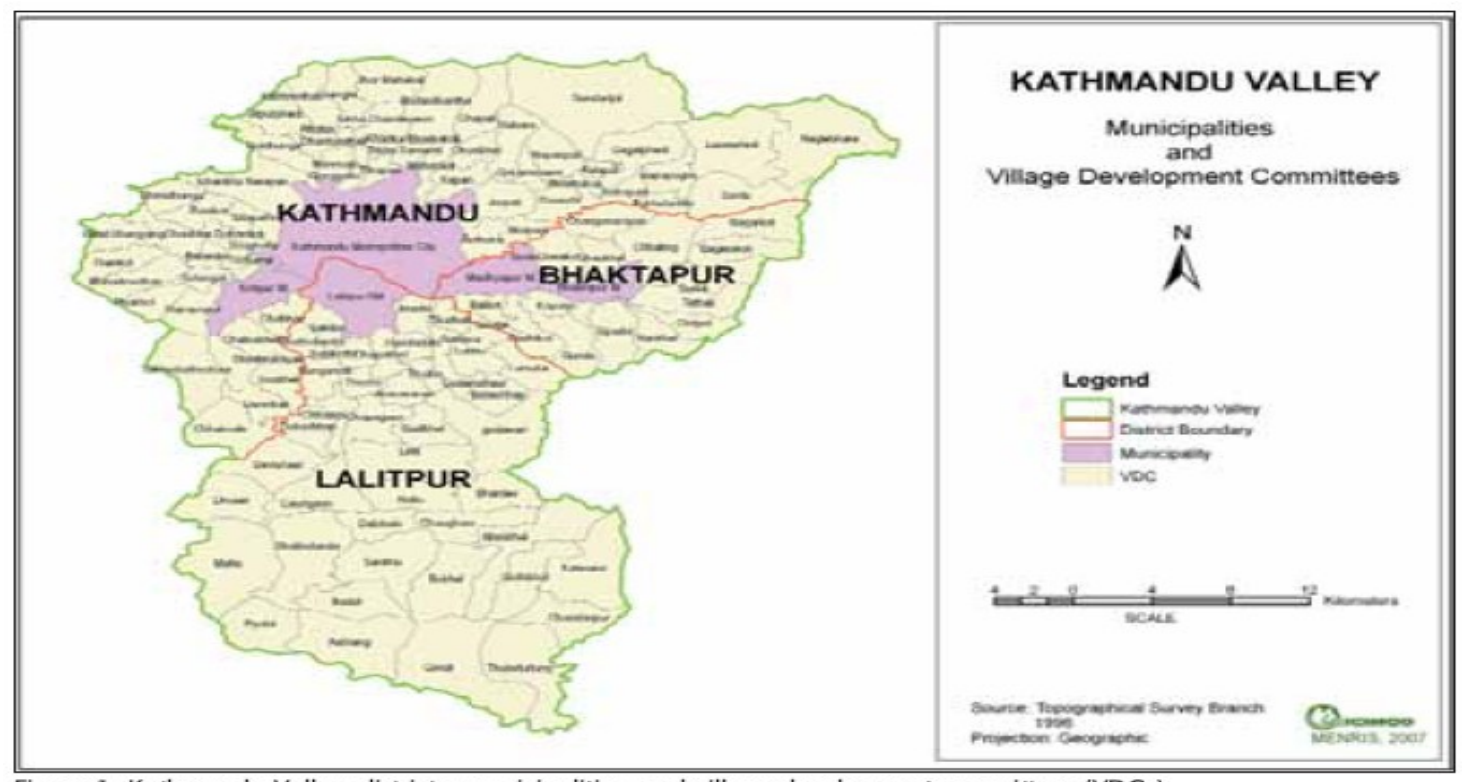

Figure 1: Kathmandu Valley: districts, municipalities, and village development committees (VDCs) 


\section{State of Demographic Profile}

The population of the three districts of Kathmandu Valley increased from 1,107,370 in 1991 to $1,647,092$ in 2001 . The annual population growth rate in Kathmandu district was $4.71 \%$. The population of Kathmandu district was 675,341 in 1991 (3.6\% of Nepal's population) and $1,081,845$ in 2001 (4.6\% of Nepal's population). The population density ${ }^{1}$ of Kathmandu district was 1,069 in 1981; 1,710 in 1991, and 2,739 in 2001.

The three districts of Kathmandu Valley consist of five municipalities and 114 VDCs. According to the Local Self Governance Act, 1999, urban areas are classified into Metropolitan

Cities, Sub-Metropolitan Cities, and Municipalities. As per this Act, there are three municipalities (Bhaktapur, Madhyapur, and Kirtipur), one sub-metropolitan city (Lalitpur), and one metropolitan city (Kathmandu) in the valley. The population in designated urban areas of Kathmandu Valley has increased considerably (Table 2.4). Urbanization has not been uniform throughout the country. Most urbanized areas are in Kathmandu Valley, which contributes significantly to the overall urbanization status of the country. The urban population density of Kathmandu Valley is 10,265 (the population is 995,966 and the area 97 sq.km.) (CBS 2003b). On the other hand, the rural population is also increasing slowly in the valley. The average annual growth of the rural population is comparatively higher than for Nepal as a whole (Table 2.5).

Table 2.4: Urban growth and urban population growth trend, 1952/54 - 20013

\begin{tabular}{|c|c|c|c|c|c|c|}
\hline Region & $1952 / 54$ & 1961 & 1971 & 1981 & 1991 & 2001 \\
\hline Kathmandu Valley & 196,777 & 218,092 & 249,563 & 363,507 & 598,528 & 995,966 \\
\hline Nepal & 238,275 & 336,222 & 461,938 & 956,721 & $1,695,719$ & $3,227,879$ \\
\hline \multicolumn{7}{|c|}{ Percentage distribution of urban population } \\
\hline Kathmandu Valley & 82.6 & 64.9 & 54.0 & 38.0 & 35.3 & 30.9 \\
\hline \multicolumn{7}{|c|}{ Level of urbanization (in \%) } \\
\hline Kathmandu valley & & & & 47.4 & 54.1 & 60.5 \\
\hline Nepal & & & & 6.4 & 9.2 & 13.9 \\
\hline
\end{tabular}

Source: CBS $2003 b$

\subsection{Driving Force}

The rapid growth in population is one of the major driving forces for the environmental degradation in Kathmandu Valley. The population growth is due to various pull factors that attract wider population to the valley. The total population of the Kathmandu Valley is the sum of local inhabitants, migrant population ${ }^{2}$, and transient population ${ }^{3}$.

Nepalese living in rural areas have correspondingly been pushed to move to urban areas by the societal perception that there are better employment prospects, infrastructure, schools, and healthcare facilities, and by their belief that they will enjoy a higher quality of life in the city. While these factors were adequate to explain urbanization and internal migration in the past and a new push factor has become vital at present. The Maoist insurgency, and the corresponding

\footnotetext{
${ }^{1}$ No of person per sq km

${ }^{2}$ Migrant population refers to internal and external migrants

${ }^{3}$ Transient population refers to those who come for temporary purpose
} 
governmental response, is pushing a considerable number of citizens, who fear for their safety and/or lives, to move to the urban areas.

The transient population is distributed sporadically throughout the valley, determined by the objectives of their visits. The main reasons for coming to the valley are higher education, medical check-ups, pilgrimages, bureaucratic formalities, visiting relatives, internal tourism, and official visits.

\subsection{State of Environment in Kathmandu Valley as per OECD Framework}

According to the framework developed by Organization for Economic Cooperation and Development (OECD) and other organizations, which has been adopted by the United Nations Environment Programme (UNEP) for the preparation of an integrated environmental assessment report of the Kathmandu Valley's Environment Outlook, the five key environmental issues in the Kathmandu Valley were:
a. Air quality and traffic management
b. Settlement patterns
c. Water resources
d. Waste management
e. Natural disaster preparedness (focused on earthquakes and land subsidence)

A Driver-Pressure-State-Impact-Response (DPSIR) Framework was used to analyze the five issues in the Kathmandu Valley. The Framework is described below and shown diagrammatic form:

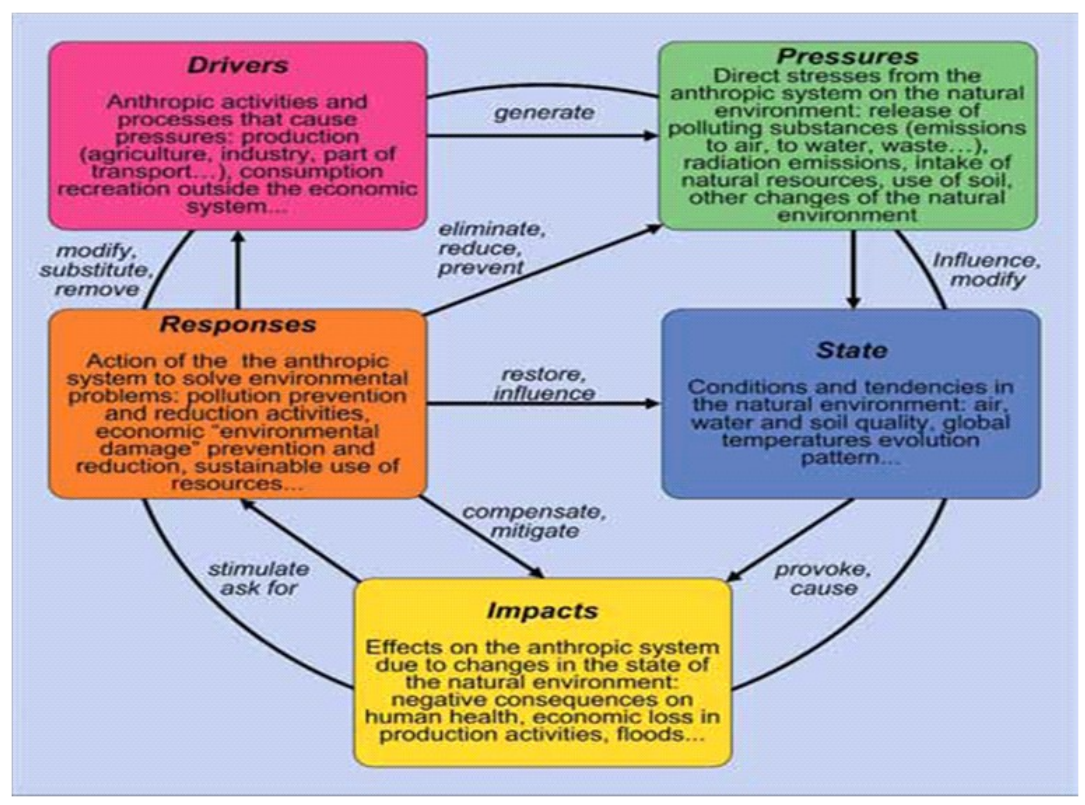




\section{Pressure}

Pressure indicators describe the variables, which directly cause environmental problems. Some of the pressures for environment of KTM Valley:

\section{[a] Lack of Employment Sectors}

People are migrating from rural areas and other urban areas of the state with the hope of getting employment opportunities in different formal sectors. The rate of migration is so high in comparison to the scope of employment in formal sectors is that all cannot get decent employment in the city. So, there is always a lack of employment opportunity. This unemployed mass never go back to their native place. They contribute to the population growth of the city leading to many other correlated environmental problems.

\section{[b] Unsystematic Settlement Pattern}

The settlement pattern of the city is greatly influenced by the rapid growth of population. The settlement pattern in KTM Valley can be classified in to two categories 1. Formal settlements and 2. Informal settlements or, slums, shanty and squatter settlements. There is always a miscombination of formal and informal settlements in many locations of the city. During the early age of KTM, i.e. in 1950s, KTM had only formal human settlements constructed by the Royal Authorities for its ministers, officers, military staff and workers. But, as the city grew and headed towards more urbanization, more formal settlements were generated by the people along with informal settlements.

\section{[c] Over-Consumption of Natural Resources}

Consumption of natural resources is always directly proportional to the population growth. More uncontrolled population leads to pressure on consumption of the natural resources of Land, water, air, forests etc. As the city grows with population and infrastructures, it destroys the proper land use pattern of the city. The present land use pattern of KTM Valley is as per the following; From the land use analysis it is observed that the percentage of the vacant land in KTM appreciably high. The city has a good potential for future development on the Western side. But rapid growth in urban population consumes more of land in an unsystematic manner causing threat to natural land resources. Over consumption of water, air, and forests are also due to the increase in the urban population in KTM Valley.

\section{[d] Inefficient Public City Transport System}

The public city transport system is not that efficient to cater good service to the public. Human settlements are going on increasing in all possible geographical directions. But the network of the public transport system is not increasing accordingly. The city bus service is available in some of the fixed routes, which was there on ten years ago. New routes and connecting routes are not coming up causing inconvenience to the passengers depending on city bus service. There is no fixed time for the city bus to leave a particular stop. The time depends on either the bus getting filled up with passengers or the next bus reaching the stop from behind and the greatest problem the buses create is that, the whole period of waiting for the passengers is spent with the engines in on position causing a lot of air pollution. 
These are the factors that discourage the public to commute by the city buses and encourage using the private vehicle to avoid inconvenience and to consume less time in travel. This increase in private vehicle ownership causes more air pollution of KTM Valley.

\section{[e] Solid Waste Management}

As per the Himalayan Times Report, (Novemeber, 2010), most urgent and acute problem of the Kathmandu city is solid waste management. There is not proper implementation of any urban policy or long term strategy for controlling or managing this issue in a effective way. The effect of urban solid wastes is not only confined to one area of the Kathmandu city environment, but it has the potentiality to cause ground water, surface water, land and air pollution. As such, with rapid growth of population, management of urban solid wastes has become a major concern to the public and is a thrust area of municipal administration of KTM Valley The quantity of solid waste generated increases with the increase in population and their changing life style and habits. Solid waste management is one of the important obligatory functions of KTM Valley and Municipal Corporation. This service falls far short of desired levels, resulting in problems of health, sanitation and environmental degradation of the city.

\section{[f] Polluting Industries}

KTM Valley is not at all an industrialized area. Still then, there are some patches of industries where we find mostly small to medium scale industries. There are many stone crushers located towards the southern side of the city. The other belts of different types of manufacturing Industries are-Bhaktapur, Lalitpur, Kathmandu Industrial Estates. These Industries put pressure on the air quality of the city. The breaks factory, stone crossing industries, uncontrolled housing are the major contributor for the pollution of the state of environment in the Valley.

\section{[g] Improper Drainage and Sewerage System}

Since Kathmandu has undulating ridge and valley topography, the valleys act as natural drains to dispose off the wastewater of the city from the west to the east through the different 'city drains', which ultimately drains in to the river "Baghmati".

The sewerage system of KTM Valley was initially designed to serve a total population of 200,000 people. With rapid pace of urbanization, it is also subsequently added with new Sewerage systems, which is not adequate enough to dispose off the sewers of the city. The congested sewerage system causes overflowing affecting environment adversely.

\section{[h] Large Scale Deforestation}

Not long time ago, before the one decade KTM Valley and adjoining regions supported a thick vegetation cover, which was popularly known as Kathmandu Ban/jungle, a part of the Kathmandu dynasty. The forest was moist deciduous type. The biodiversity was remarkably rich. But with the growth of population and expansion of city, large-scale deforestation took place. Concrete jungles disturbing the flora and fauna of the region replaced the natural Jungle. This large-scale deforestation had direct impact on the microclimate of the region.

\section{[i] Tourism Aspect}

Kathmandu Valley is known for its ancient art, culture, craftsmanship, and numerous monuments of historic and archaeological importance. One of the popular tourist destination in the South 
Asia. Its enchanting natural beauty and, temple sculpture and strategic location always attracts millions of tourists and holy devotees to the Kathmandu valley. UNESCO has described Kathmandu as a 'living heritage site'. The valley has a number of temples, palaces, monasteries, and Buddhist stupas that are centuries' old. A unique feature is the religious co-existence of Hindus and Buddhists, as they worship at the same religious sites. Tourists come to Kathmandu Valley throughout the year with heavy flow during the winter season. This tourist population is also sufficient to contribute to the driving force of growing population affecting the environmental state of KTM valley. The majority of the income of the valley comes from the hotel industry, which also put extra burdens in terms of garbage collection and waste disposal.

\section{[J] Natural Disaster}

Infrastructural development in the valley facilitates the concentration of population from other parts of the country. Encroachment on land, haphazard construction of buildings, and rapid urbanization lead to rapid population growth No building codes are implemented although they were introduced in 1994; although Lalitpur Sub-Metropolitan City has implemented a Nepal National Building Codes since 16th January, 2003 to make city dwellers aware of the risk of earthquakes. Sky scrapers are being built without taking sub-surface geology into account.

No great earthquake has been reported between the longitude of Kathmandu and Dehradun for 300 years, and that could be a potential area for a big earthquake in future. This location lies between two great earthquake locations (the Nepal-Bihar earthquake of 1934 and the Kangra earthquake of 1905).Geological faults, fragile geological conditions, high intensity rainfall during monsoon, unplanned land use and insufficient fuel leading to deforestation are the forerunners to landslide occurrences. Figure 48 gives the location of landslides in the Kathmandu subsidence.

\section{Impacts}

The substandard state of environment, due to different environmental pressure, causes adverse impacts on the Environment and ultimately on human health. The impacts may be summarized as:

- Lack of employment opportunity causes mass unemployment resulting in the growth of many informal sectors through out the city.

- Growth of informal settlements like slums, shanty and squatter settlements causes heterogeneity in settlement pattern \& loss of heritage. The slum dwellers are deprived of good housing, proper sanitation, clean water and air and other minimum facilities, which endanger the health, safety or morals of the inhabitants. The house of the informal settlements are very much susceptible to natural and man made disasters due to its low quality of construction, closeness of houses and temporary nature which causes threat to life and property all the time.

- Over consumption of natural recourses cause threat towards sustainability of our future generation to come.

- Due to the encroachment of the natural drainage paths for the purpose of constructing buildings and infrastructures, the smooth discharge of runoff water of heavy drown pour is not possible causing city flooding at some specific localities of Kathmandu Valley. 
- Increased concentration of pollutants emitted from the running vehicles and industries cause increased number of lungs diseases and respiratory problems of the city dwellers. Children are the worst affected mass of the city.

- Increase in the number of vehicles also cause noise pollution at the city centers. Noise pollution affects the human beings physiologically and psychologically too. Long and continuous exposure to higher level of noise causes irritation and sometimes health problems too.

- Increased number of vehicles also causes traffic congestion.

- Improper solid waste management reduces the aesthetic value of the environment. If not cleared up in regular intervals, i.e. daily, it emits bad odor or, fowl smell causing air pollution of the environment. If proper techniques are not adopted starting from the collections till disposal, it may create health hazards.

- Overcrowding of people due to different factors like Migration, Tourism etc. over use the open water bodies located at different part of the whole old town areas, there by disturbing aquatic eco-system.

- Large scale deforestation and increase in urbanization activities affect the prevalent micro climatic system of Kathmandu Valley. Since last couple of years heat island effect is very much observed during summer season. There is a very sharp rise in the maximum day temperature even up to the $35 \mathrm{C}$ in the summer, which is uncommon for a urban valley like Kathmandu, located in the mountain slopes. A very big difference in the day's maximum and minimum temperature is observed which causes many health problems.

- Over flow of sewers cause health hazards and also gives foul smell.

Table 3.8: Health impacts of $\mathrm{PM}_{10}$ in Kathmandu Valley in 1990

\begin{tabular}{|l|c|c|c|}
\hline \multirow{2}{*}{\multicolumn{1}{c|}{ Types of Health Impact }} & \multirow{2}{*}{ No. of Cases } & \multicolumn{2}{c|}{ Value (NRs.) } \\
\cline { 3 - 4 } & & Specific & Total $\left(\times \mathbf{1 0}^{\mathbf{3}}\right)$ \\
\hline Excess Mortality & 84 & 340,000 & 28,644 \\
\hline Chronic Bronchitis & 506 & 83,000 & 41,988 \\
\hline Restricted Activity Days & 475,298 & 56 & 26,617 \\
\hline Emergency Room Visit & 1945 & 600 & 1167 \\
\hline Bronchitis in Children & 4847 & 350 & 1,697 \\
\hline Asthma Attacks & 18,863 & 600 & 11,318 \\
\hline Respiratory Symptom Days & $1,512,689$ & 50 & 75,634 \\
\hline Respiratory Hospital Admissions & 99 & 4160 & 415 \\
\hline Total & & & 187,480 \\
\hline
\end{tabular}

Source: Shah and Nagpal 1997 


\section{Responses}

- Some development programmes were taken up, during the last decades by the Nepal Housing Board [NHB] and Kathmandu Metropolitan Development Authority [KMDA] in the support of improving the quality of living of the slum dwellers and for reducing the pressure in the existing slum pockets. Some of the programmes are of direct in nature and others are indirect efforts.

\section{Efforts}

- To regulate the proper land use planning inside the Kathmandu city, KMPDA was formed.

- Unleaded gasoline replaced the leaded one to lower lead content in the air pollutants.

- Opening of vehicular emission test centers at different locations of the city.

- Construction of improved roads and providing other infrastructure facilities for smooth flow of traffic.

- Nepal Pollution Control Board was formed. Among its main objectives, one is to check and control pollution caused by the industries.

- Kathmandu Metropolitan Municipal Corporation is increasing the capacity of the sewerage system in phase wise manner.

- Avenue plantation and roadside plantation is going on from the dept. of Forests.

\section{Policy Gaps}

1. No policy so far formulated to make rural sides more attractive to reduce rural to urban migration

2. Employment generating schemes not initiated by the government.

3. No policy is thought of to create an intermediate urban center between Kathmandu Valley and the rural areas to reduce pressure on Kathmandu Valley.

4. No clear-cut policy on the slum and squatter settlements has been formulated so far

5. Development of Kathmandu Valley without effectively implementing the existing master plan.

6. Slum up gradation and resettlement programmes fail or don't get materialized as those are dealt without proper understanding peoples' need and affordability.

7. Lack of strict enforcement of Laws.

8. Lack of future estimate by the Govt.

9. Corruption at each level hampers the process of up gradation of the environmental status of Kathmandu Valley.

10. Lack of infrastructural facility and fund.

11. Fund generation process of the municipality not properly implemented.

12. Lack of coordination between different government departments, NGOs and private groups.

13. Lack of peoples' awareness.

14. Inefficient top-down approach in management.

15. Lack of peoples' participation in pollution control programmes. 


\section{Recommendations}

a. Policy should be formulated and implemented to increase the attractiveness of the rural side to reduce man-drain to the city. Rural areas must be provided with better facilities of good health service, better education and employment opportunity to restrict migration.b.Building Intermediate City to serve as link between Kathmandu Valley and nearby rural areas to check the population growth. c.Various income generating schemes should be introduced with the assistance of the government followed by skill development programmes in specific areas. $d$. Some clear-cut policy on the slum and squatter settlement should be formulated to regulate the growth of informal settlements. E.Peoples need and affordability must be thoroughly analyzed before formulating any slum up-gradation and resettlement programme. f.The existing master plan of Kathmandu Valley must be reviewed and revised thoroughly by a team of senior experts from different fields and then implemented strictly. g.Proper land use planning must be done., h.Public city transport network should be made efficient to discourage private vehicle ownership and encourage using public transport system to reduce air pollution, noise pollution and traffic congestion during the peak hours.i.Condition of engines of vehicles must be verified periodically by checking the emission. This emission checking process must be made very strict with heavy amount of penalty for the violators.j.Placement of the catalytic converters in the exhaust pipe must be made compulsory for each and every vehicle.k.Availability of better quality of gasoline with high-octane value must be ensured in all petrol pumps. 1.Infrastructure developments like construction of more and more improved roads, interchange, intersections and flyovers must be provided to allow smooth flow of traffic. All these facilities along with better traffic management can reduce pollution loads.m.People should be encouraged to buy four-stroke motorbike compared to two stroke bikes to reduce pollution.m. The whole process of solid waste management should be made stream lined.n.Collection bins must be provided at different locations for organized garbage collocation. Different colored bins with clear writings on the sides with local, national and with English languages must be placed together for segregated collection of different types of urban solid waste. These placement patterns should be repeated at every 100 meter distance or, for every 100 people so that, people do not throw garbage here and there.o.The people of the municipal corporation must clean all the collection bins early in the morning hours every day.p.Segregation of the solid wastes is a must. The recyclable wastes like plastics, glass, metals etc must be sent for recycling. The other wastes can be disposed off suitably.q.Creating awareness among the public about solid waste management.r.Encourage 3-R principle i.e. Reduce, Reuse, and Recycle.s.EIA must be made compulsory for every industry or, project.t.Pollution from industries must be controlled by adoption of sophisticated new technology and end of the pipe technology.u.The stone crusher industries causing lot of air pollution should be shifted and relocated sufficiently away from the master plan area boundary of Kathmandu Valley.v.Production of noise from all sources expecting emergency requirements should be banned between $9.00 \mathrm{pm}$ to $6.00 \mathrm{am}$. w.Pneumatic horns of the vehicles should be banned altogether.x..City sewerage system must be made updated by redesigning, considering future growth.y.Urban sprawling in the vicinity of the natural drainage channels not only creates unhealthy situation but also frequent urban flooding caused due to heavy rain. Extra attention should be given at the time of granting planning permission.z.Hazardous waste generated must be disposed off properly irrespective of their quantity. 
Other Measures Sustainable Environmental Management in Kathmandu City:

- Large-scale avenue plantation must be encouraged.

- The developmental activities should be always interdisciplinary.

- Green agenda, Brown agenda and White agenda must be emphasized.

- Government must find means to generate funds for environmental protection.

- Improved techniques like GIS should be followed in town planning.

- Strict enforcement of laws.

- Awareness and capacity building among the public along with stakeholders consultation.

- Develop public-private-partnership [P.P.P] in protecting the environment of Kathmandu Valley.

\section{REFERENCE}

[1] ADB/ICIMOD (2006) Environment Assessment of Nepal Emerging Issues and Challenges. Kathmandu: ICIMOD and ADB

[2] Kathmandu Valley Environmental Outlook,(2007),ICIMOD

[3] Amatya, S. (2006) Water and Culture. Kathmandu: Jalsrot Vikas Sansthan (JVS)

[4] CBS (1994) Census of Manufacturing Establishments Nepal 1991 - 1992, National Level. Kathmandu: Central Bureau of Statistics

[5] CBS (2002) Population Census of Nepal, 2001: Village Development Committee/ Municipality (Central Development Region).Kathmandu: Central Bureau of Statistics

[6] CBS (2003b) Population Monograph-2003. Kathmandu: Central Bureau of Statistics

[7] CBS (2004) Nepal Living Standards Survey Report

[8] CBS (2005) Poverty Trends in Nepal (1995-96 and 2003-04).Kathmandu: Central Bureau of Statistics

[9] DOH (2006) Annual Report 2005

[10] Quality Control Section, Department of Health Services, Teku, 2006

[11] FAO (1994) Indigenous Methods of Sustainable Vegetable Production in the Kathmandu Valley

[12] Nepal. Bangkok: Regional Office for Asia and Pacific, Food and Agriculture Organization of the United Nations

[13] HFA (1991) Kathmandu Valley Urban Development Plans and Programmes. Kathmandu: Government of Nepal, Department of Housing and Urban Development/Halcrow Fox and Associates

[14] Dordrecht (The Netherlands): Kluwer Academic Publishers Pradhan, P.K.; Pradhan, B. (2006) Environment and Natural Resources: Concepts, Methods, Planning and Management

[15] Kathmandu: Stanley/M-M/EAST Tebbutt, T.H.Y. (1992) Principle of Water Quality Control

[16] London: Pergamon Press Tuladhar, D. (2006) Environmental Change along the Bagmati River in Kathmandu Valley

[17] Dissertation for Master's degree, Central Department of Geography, Tribhuvan University, Kathmandu, Nepal Tuladhar, T.M. (1998) Urban Growth 
[18] Basyal, V.; Pokhrel, D. (2004) Sustainable Options for Treatment and Disposal of Hazardous Health Care Waste, draft report for National Health Research Council and World Health Organization, Kathmandu

[19] Sharma, P. (2003) 'Urbanisation and Development,' in Population Monograph of Nepal Volume I. Kathmandu: His Majesty's Government of Nepal, Central Bureau of Statistics

[20] Timilsina, B.P. (2004) Country Report of Nepal - Management of Urban Water Environment 